\title{
DEVELOPMENT OF AN OPEN-SOURCE OBJECT FLIGHT SPEED MEASURING SETUP FOR INDOOR MEASUREMENTS
}

\author{
Fatih AKKOYUN* ${ }^{1}$, Alper B. TURAN ${ }^{1}$, Oğuzhan KARASU ${ }^{1}$, Erturan YETISŞİN ${ }^{1}$, \\ Mert HATİPOĞLU ${ }^{1}$, Nabia KHALİD ${ }^{2}$
}

Accepted: 2021-07-12

DOI: 10.47118/somatbd.952881

\begin{abstract}
Time of flight measurement is an important procedure for indoor object flight speed measurement applications. Measuring a fast-moving object is very difficult such as military and sport shooting. Today, there is a requirement for measuring high-speed objects using a cost-effective solution. The speed detection processing requires two referencing points from flight start to end. The difference between these two points and time parameters leads to calculating speed. In-flight speed detection applications mostly an object is thrown by a launcher and measurements are conducted in a linear horizontal measurement line. The terminals of this line are referred to these two points. There are light-based solutions such as infra-red (IR) sensors, fast cameras for indoor speed measurement. However, commercial solutions based on sensors or fast cameras are expensive options and these solutions are not easily affordable for research facilities and laboratories with low-budget. In this study, an object flight speed detection setup is demonstrated for indoor measurements. The accuracy of the demonstrated setup was found 94\%. The results show that is possible to use a microcontroller (MCU) with two IR sensor for calculating the flight speed with low-cost and high accuracy.
\end{abstract}

Keywords: Time of flight, indoor speed measurement, microcontroller, IR sensor.

\section{İÇ ORTAM ÖLÇÜMLERİ İÇİN AÇIK KAYNAKLI NESNE UÇUŞ HIZI ÖLÇÜM DÜZENEĞİ GELİ̧̧TIRILLMESI}

\section{ÖZET}

Uçuş süresi ölçümü, iç mekân nesne uçuş hızı ölçümü uygulamaları için önemli bir prosedürdür. Askeri veya atış sporlarında ki gibi hızlı hareket eden nesneleri ölçmek çok zordur. Günümüzde, uygun maliyetli bir çözüm kullanarak yüksek hızlı nesneleri ölçmek için bir koşul vardır. Hız algılama işlemi, uçuşun başlangıcından sonuna kadar iki referans noktası gerektirir. Bu iki nokta ve zaman parametreleri arasındaki fark, hızın hesaplanmasını sağlar. Uçuş sırasında hız algılama uygulamaları çoğunlukla firlatıcı tarafından bir nesne firlatılır ve ölçümler doğrusal bir yatay ölçüm hattında yapılır. Bu hattın kutupları bu iki noktayı ifade eder. Kızılötesi (IR) sensörler, iç mekân hız ölçümü için hızlı kameralar gibi 1şık tabanlı çözümler bulunmaktadır. Bununla birlikte, sensörlere veya hızlı kameralara dayalı ticari

\footnotetext{
${ }^{1}$ Aydın Adnan Menderes University, Mechanical Engineering Department, 09010, Efeler, Aydın, Turkey.

${ }^{2}$ National University of Sciences and Technology, Department of Computing, SEECS, 44000, Islamabad, Pakistan.

${ }^{* 1}$ Corresponding author e-mail: fatih.akkoyun@adu.edu.tr
} 
çözümler pahalı seçeneklerdir ve bu çözümler, düşük bütçeli araştırma tesisleri ve laboratuvarlar için kolayca karşılanamaz. Bu çalışmada, iç mekan ölçümleri için bir nesne uçuş hızı algılama düzeneği gösterilmektedir. Bu düzeneğin doğruluğu \%94 oranında bulunmuştır. Sonuçlar, uçuş hızını düşük maliyetli ve yüksek doğrulukla hesaplamak için iki IR sensörlü bir mikro denetleyici (MCU) kullanmanın mümkün olduğunu göstermektedir.

Anahtar Kelimeler: Uçuş süresi, iç mekan hız ölçümü, microcontroller, IR sensor.

\section{Introduction}

In indoor object flight speed measuring applications, the flight speed determining process can be accomplished using fast cameras or light sensor-based devices (Baird et al., 2005; Mao et al., 2012). Both options provide effective solutions for precisely capturing object position and time data together (Ishii et al., 2017; Jezeršek, 2009). Today, it is necessary for measuring high-speed objects using a cost-effective solution (Cho et al., 2016; Sozen et al., 2019). In real experiments, various parameters are effecting the precision and accuracy of a flight measuring setup such as object launcher, size, and shape of objects, the response time of the sensor, frame per second (FPS) for fast cameras (Akkoyun et al., 2021). Today a fast camera with a high FPS parameter is a good option despite the high cost. However, for many laboratories, a high-cost solution is not the first option (Akkoyun \& Ozcelik, 2020, 2021).

There are studies (Chen et al., 2011; Gerschuni \& Pardo, 2013; Xia et al., 2011) related to object speed detection using a camera with computer vision technology. In one example, the flying object speed detection approach is proposed using a camera and a complex image processing method. In another example, infrared imaging technology is used for outdoor applications. An adaptive approach with $90 \%$ accuracy is offered, however, the solution proposes a complex algorithm using fuzzy logic. There are limited studies on low-cost object flight speed measuring solutions for indoor applications. An indoor application (Cho et al., 2016) is offering a solution using image processing techniques such as Canny Edge, Contour, Calibration, Transform process, and Threshold for detecting the high-speed flying objects. In one study (Shrivastava et al., 2006), binary proximity sensors are used for target tracking effectively. Another study (Wooyoung Kim et al., 2005) uses these sensors to track objects with $100 \%$ accuracy. However, both studies are only focusing on object absence and presence. Mostly, the proposed approaches are offering complex and high-cost solutions for a single object flight speed measurement.

This study offers a low-cost, accurate and simple solution to measure flight time to calculate object flight speed for indoor applications. For this, two infrared sensors which are integrated into a microcontroller unit are employed. Compared to an industrial high-speed camera, which is the gold standard for evaluating rapid events, the infrared sensor-based approach yielded accurate results with a very low-cost system. This approach can be potentially adopted in other industrial and research applications where measuring the time of flight is critical.

\section{Material and Method}

In the study, the object flight determining stage is accomplished using a microcontroller (MCU) and two infrared (IR) light sensors-based solutions. An experimental setup is prepared for preparing a fixed distance between two IR sensors. This constant distance and microcontroller (MCU) elapsed time parameters are used together to calculate object flight 
speed. An internal MCU timer is set to initiate time when an object enters the field of the first sensor. The second sensor is used to stop this timer and the elapsed time is determined by the difference. The known fixed distance and measured time parameters are composed to extract speed results. The result of measurements is transferred to a personal computer (PC) via a USB interface. The general structure of the experimental setup is shown in Fig. 1.

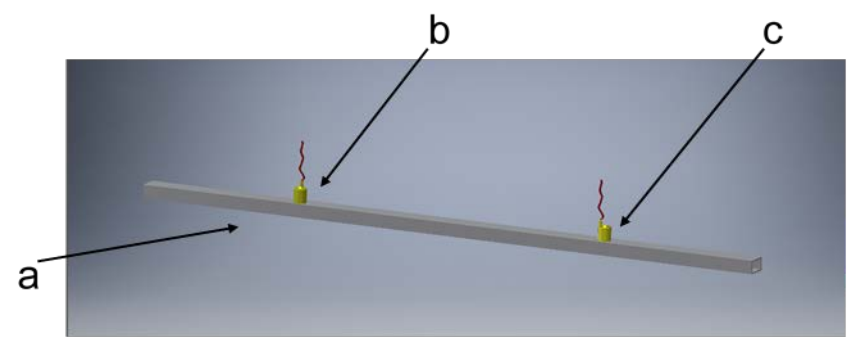

Fig. 1. The structure of the system, a) sensor holder, b) IR sensor A, c) IR sensor B.

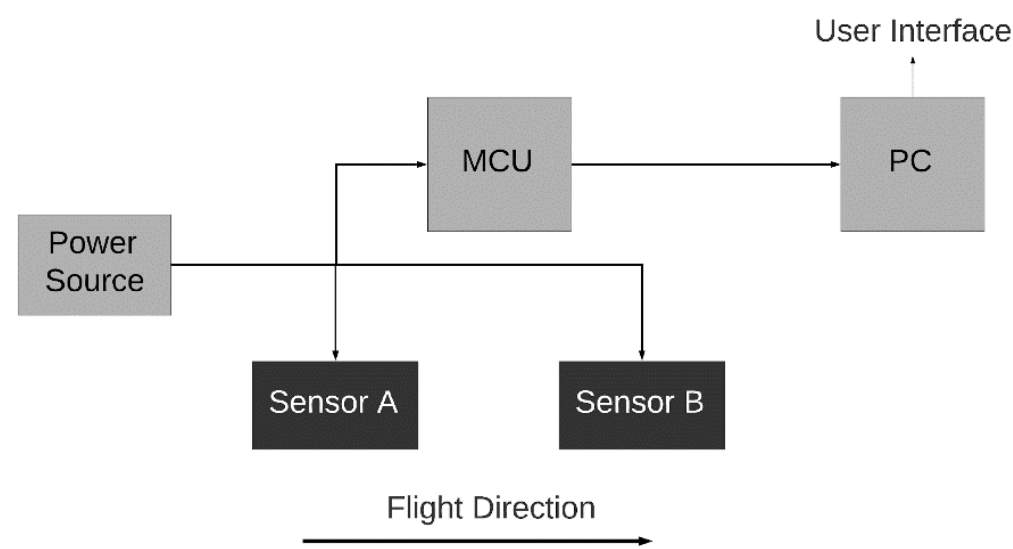

Fig. 2. Block diagram of the system.

The block diagram of the measurement system is shown In Fig.2. In the flight measuring system, the two IR sensors are connected to digital pins of the MCU. Thus the pulses generated by an object that passes through the sensors sensing areas are used to start and stop a built-in timer inside the MCU. The first triggering pulse is used to start the timer to count from zero and the second triggering pulse is set to stop the timer. Both triggering inputs are connected to interrupt pins of the MCU for signal capturing operations. These interrupt pins are adjusted to capture input triggering signals for rising edges only. In the last stage, the MCU calculates the elapsed time from the first sensor pulse to the second one. The time parameter is multiplied with the inverse of a constant distance which is a fixed distance between these two sensors. Then the result is transferred to a personal computer (PC) over USB for recording the calculated speed. The resulting data is obtained from the terminal screen with the serial communication method. The developed algorithm of the system is implemented using embedded C programming language. The flow chart of the software is shown in Fig. 3. 


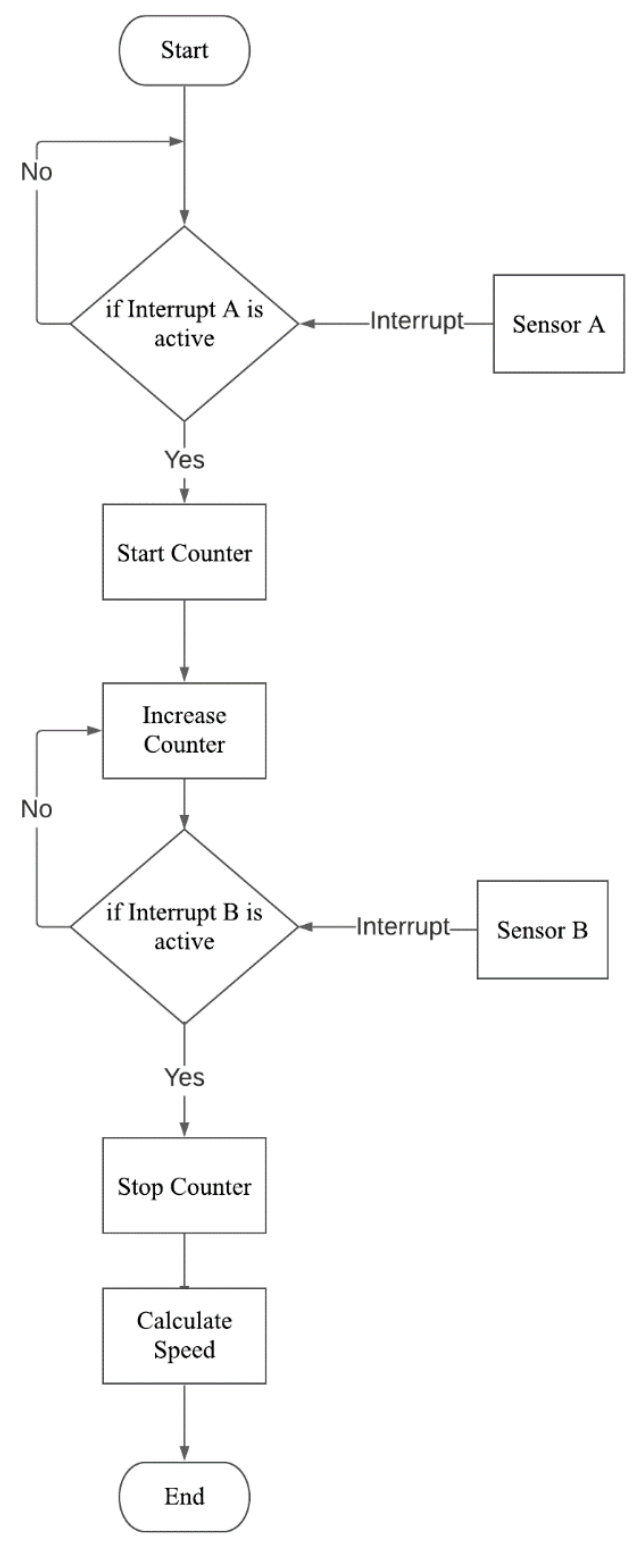

Fig. 3. Flowchart of the system.

An 8-bit MCU (Atmel Atmega32A) is used to implement time-dependent operations and object sensing duties. The communication between PC and MCU was accomplished using a USB converter (FT232). An external $16 \mathrm{MHz}$ Crystal oscillator assembled to the MCU. IR sensors were connected to a digital input pin of the MCU to detect object presence. The wiring diagram of the system was shown in Fig. 4. 

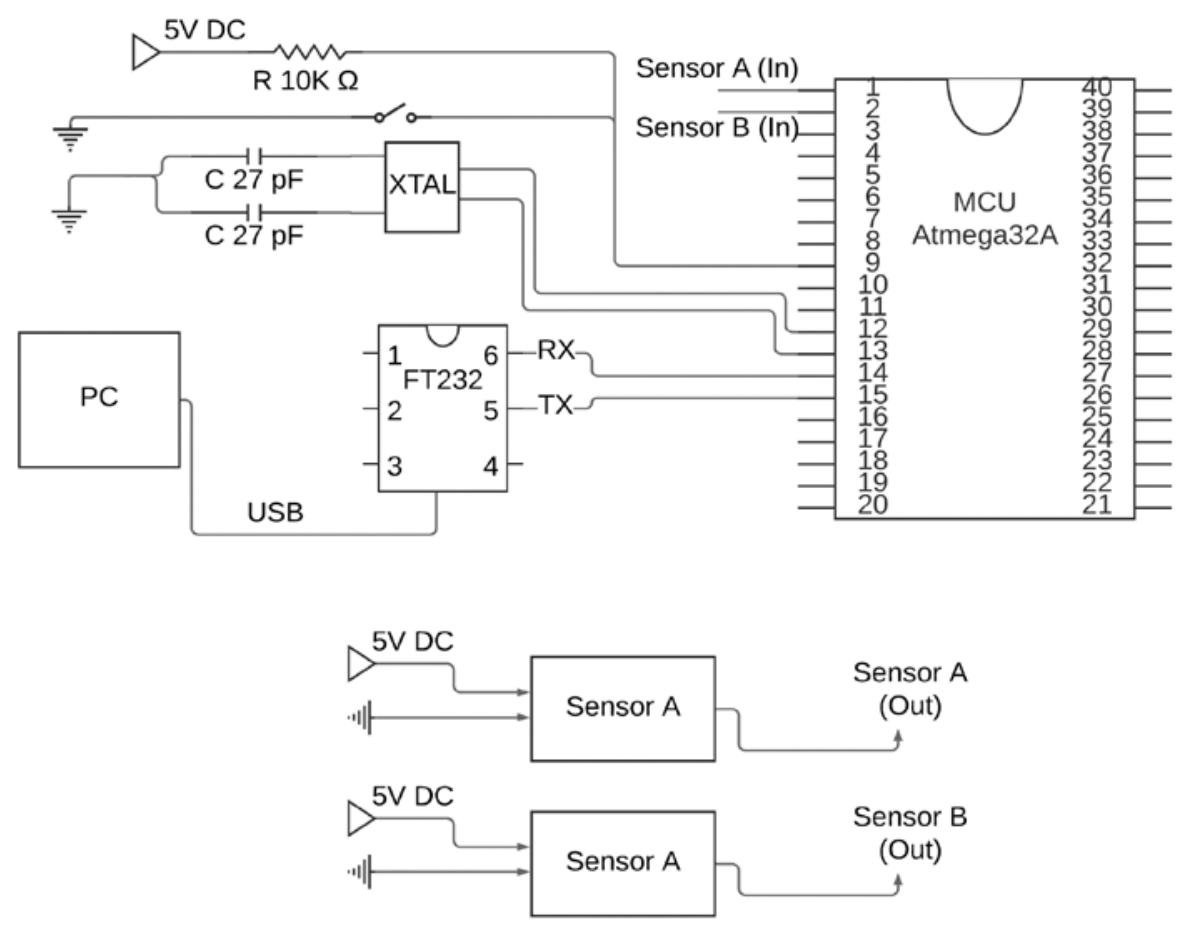

Fig. 4. Wiring diagram of the system.

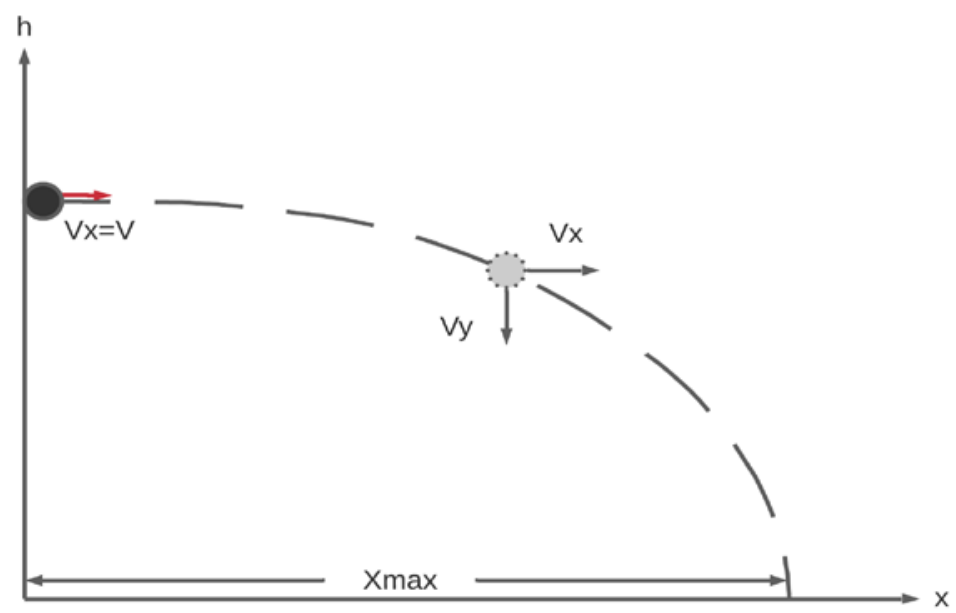

Fig. 5. Projectile motion with gravity. 


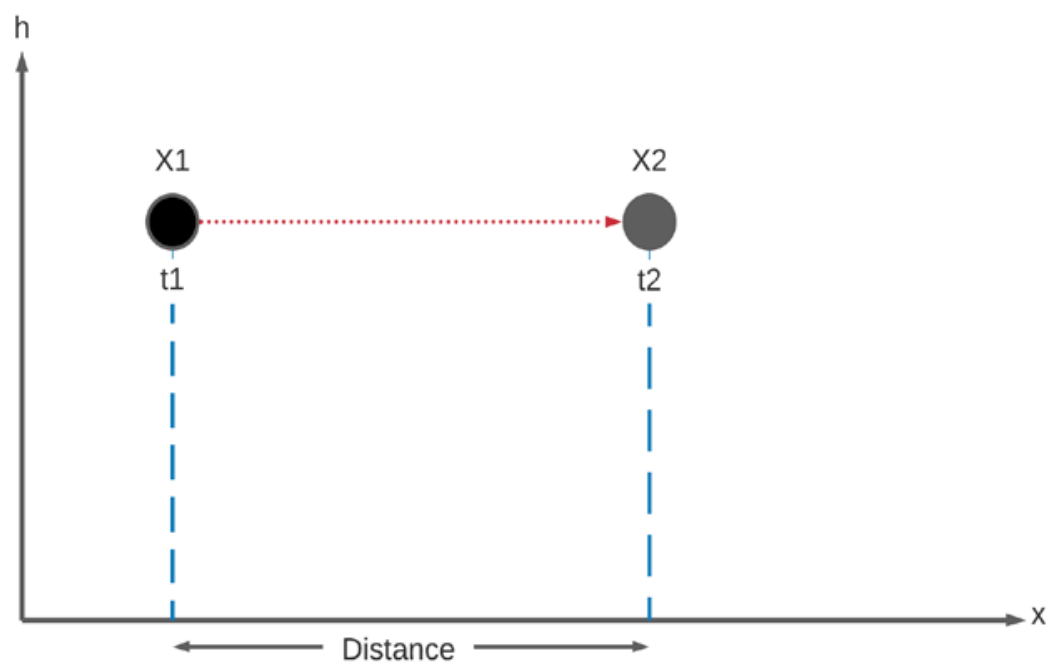

Fig. 6. Projectile motion with neglected gravity.

The projectile motion (Fig. 5) is the movement of an object thrown or launched into the air. The acceleration of gravity is the only effect that the object is subjected to. The object has a two-dimensional motion in horizontal and vertical directions depending on gravitational force and initiation force. The initial velocity (Eqn. 1), initial vertical velocity (Eqn. 2), initial vertical-horizontal (Eqn. 3), and velocity at the time 't' (Eqn. 4) are used to obtain Eqn 5 and 6. The vertical velocity of the object is neglected (Fig. 6). Taking into account all these points the Eqn 7 can be obtained where time, distance, and velocity are ' $t$ ', ' $\mathrm{X}$ ', ' $\mathrm{V}$ ', respectively.

$$
\begin{array}{lc}
v_{0} & \text { Eqn. } 1 \\
V_{0 y}=V_{0} \sin \theta & \text { Eqn. } 2 \\
V_{x}=V_{0} \sin \theta & \text { Eqn. } 3 \\
V_{x}=V_{0} x=V_{0} \cos \theta & \text { Eqn. } 4 \\
V_{y}=V_{0}-g t=V_{0} \sin \theta-g t & \text { Eqn. } 5 \\
V_{2}=V_{y 2}+V_{02} & \text { Eqn. } 6 \\
X(\text { distance })=V(\text { velocity }) x t(\text { time }) & \text { Eqn. } 7
\end{array}
$$

In the experimental stage, forty-nine measurements were accomplished to evaluate the accuracy of the system. The objects are launched to achieve horizontal movement which is parallel measuring and sensor positions. Each object was passed inside the measuring area of 
the first and second sensor, sequentially. Minimum two-hundred-millimeter vertical distance covered for each measurement.

A launcher is adjusted to throw a round-shaped object. The launcher is assembled with a pressurized air tank for acquiring initial force. The tank is refilled after each launching step. In the experiments, different speeds were examined, and each step was compared with the sensor and camera together for these speeds.

\section{Results and Discussion}

In the experiments, a correlation is obtained from object flight measurements by examining the pressure and speed relationship. The measurements were conducted with a fast camera and pressurized tank together. A positive correlation was obtained between the pressure as input and speed as output, and the correlation coefficient was found above 0.95 . The result is shown in Fig. 7 for speed and pressure parameters correlation.

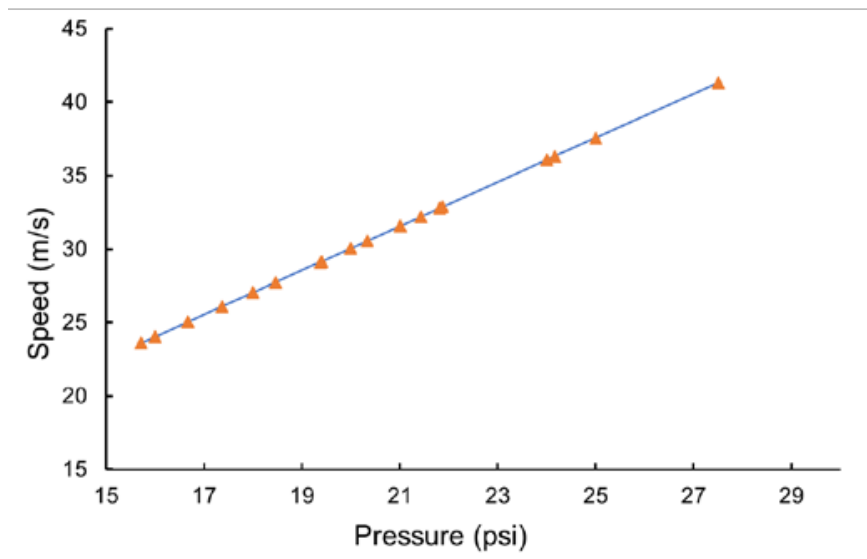

Fig. 7. Pressure and speed relationship.

The accuracy of the system was evaluated by increasing the object flight speed. The speed of the thrown object was measured using both the fast camera and IR sensors. The fast camera and IR sensor measurements are shown close accuracy. The standard deviation was found $4 \%$ for forty-nine measurements. In Fig. 8 the accuracy of the measuring system concerning object flight speed is demonstrated. In the light of conducted experiments, the accuracy of the demonstrated setup was found $94 \%$. 


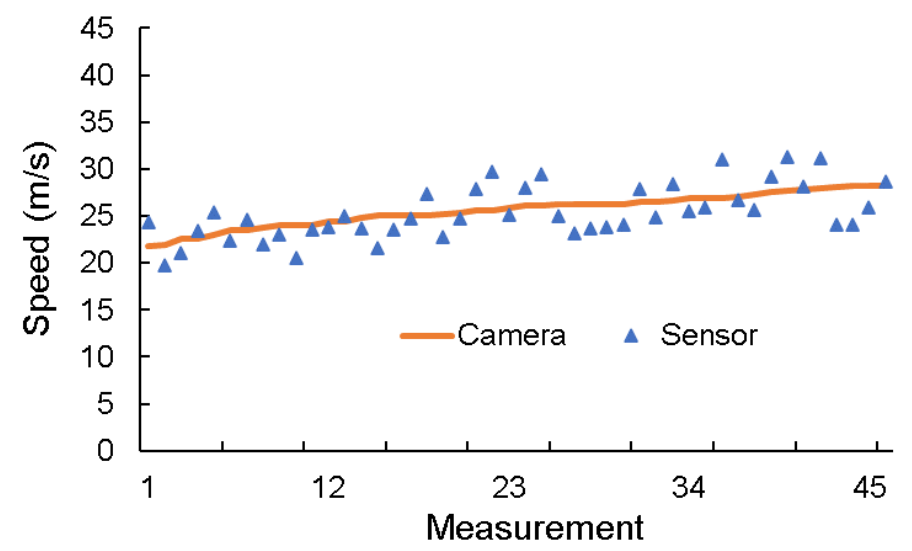

Fig. 8. The accuracy of setup concerning object flight speed.

The experiments indicate that there is a positive correlation and high accuracy between speed and IR sensor. The results show that the study is providing a cost-effective solution for many in-door flight speed applications using a low-cost MCU and two IR sensors together. Considering the importance of automation and smart process flows, achieving low-cost sensorbased solutions for the automated analysis of time-of-flight measurements is an important step within the domain of open-sourced tools and methods development. This work can be considered to be an open-sourced system that only depends on minimalistic components that are available to the public. The inequality of the research facility budgets and research funds across the globe makes it almost impossible for researchers from developing countries to adopt the necessary research protocols, and conduct internationally valid academic and industrial research and development. The movement of the open-sourced instrumentation and protocol development is critical for the future and sustainability of the research in developing countries. The work presented herein aims to contribute to this movement by providing affordable and widely available tools to achieve valuable measurement and research capacities.

\section{CONCLUSION}

This study demonstrated an object flight speed measurement setup that is suitable for indoor measurement applications. The proposed solution continuously detects object presence and initiates an in-built hardware counter inside MCU. The experiments were conducted in a fixed measurement line. The study shows that it is possible to measure an indoor flying object at a very low cost using an MCU-based solution. The accuracy and precision parameters are high enough to characterize the speed of measured objects. Thus, the study offers a simple and low-cost with high accuracy object flight measurement system that is suitable to use for many research facilities. 


\section{REFERENCES}

Akkoyun, F., Ercetin, A., Aslantas, K., Pimenov, D. Y., Giasin, K., Lakshmikanthan, A., \& Aamir, M. (2021). Measurement of Micro Burr and Slot Widths through Image Processing: Comparison of Manual and Automated Measurements in Micro-Milling. Sensors, 21(13), 4432. https://doi.org/10.3390/s21134432

Akkoyun, F., \& Ozcelik, A. (2020). A simple approach for controlling an open-source syringe pump. European Mechanical Science, 4(4), 166-170. https://doi.org/https://doi.org/10.26701/ems.769837

Akkoyun, F., \& Ozcelik, A. (2021). Rapid Characterization of Cell and Bacteria Counts using Computer Vision. Türk Doğa ve Fen Dergisi. https://doi.org/10.46810/tdfd.902441

Baird, E., Srinivasan, M. V., Zhang, S., \& Cowling, A. (2005). Visual control of flight speed in honeybees. Journal of Experimental Biology, 208(20), 3895-3905. https://doi.org/10.1242/jeb.01818

Chen, Y.-L., Wu, B.-F., Huang, H.-Y., \& Fan, C.-J. (2011). A Real-Time Vision System for Nighttime Vehicle Detection and Traffic Surveillance. IEEE Transactions on Industrial Electronics, 58(5), 2030-2044. https://doi.org/10.1109/TIE.2010.2055771

Cho, C., Kim, J., Kim, J., Lee, S. J., \& Kim, K. J. (2016). Detecting for high speed flying object using image processing on target place. Cluster Computing, 19(1), 285-292. https://doi.org/10.1007/s10586-015-0525-x

Gerschuni, M., \& Pardo, A. (2013). Bus Detection for Intelligent Transport Systems Using Computer Vision (pp. 59-66). https://doi.org/10.1007/978-3-642-41827-3_8

Ishii, M., Isokawa, H., Miyazaki, T., \& Sakaue, H. (2017, January 9). Surface State Measurement of a Free-Flight Object by Motion-Capturing Method. 55th AIAA Aerospace Sciences Meeting. https://doi.org/10.2514/6.2017-0943

Jezeršek, M. (2009). High-speed measurement of foot shape based on multiple-laser-plane triangulation. Optical Engineering, 48(11), 113604. https://doi.org/10.1117/1.3265522

Mao, X., Inoue, D., Kato, S., \& Kagami, M. (2012). Amplitude-Modulated Laser Radar for Range and Speed Measurement in Car Applications. IEEE Transactions on Intelligent Transportation Systems, 13(1), 408-413. https://doi.org/10.1109/TITS.2011.2162627

Shrivastava, N., Madhow, R. M. U., \& Suri, S. (2006). Target tracking with binary proximity sensors. Proceedings of the 4th International Conference on Embedded Networked Sensor Systems - SenSys '06, 251. https://doi.org/10.1145/1182807.1182833

Sozen, A., Gucluer, S., \& Kilinc, C. (2019). The heat transfer enhancement of concurrent flow and counter current flow concentric tube heat exchangers by using hexagonal boron nitride/water nanofluid. Thermal Science, 23(6 Part B), 3917-3928. https://doi.org/10.2298/TSCI180213283S

Wooyoung Kim, Mechitov, K., Jeung-Yoon Choi, \& Soo Ham. (2005). On target tracking with binary proximity sensors. IPSN 2005. Fourth International Symposium on Information Processing in Sensor Networks, 2005., 301-308. https://doi.org/10.1109/IPSN.2005.1440939

Xia, L., Chen, C.-C., \& Aggarwal, J. K. (2011). Human detection using depth information by Kinect.CVPR2011 WORKSHOPS, $15-22$. https://doi.org/10.1109/CVPRW.2011.5981811 